\title{
The Utilitarian Functions and the Nature of Vehicle Inscriptions and Stickers in Southwestern Nigeria.
}

\author{
Olusegun A. Faniran, Reuben 0. Ikotun \& Abiodun Oloyede \\ roikotun53@gmail.com \\ Oșun State College of Technology, Ėsà-Òkè, Nigeria, \\ Ekiti State University, Ado-Ekiti, Nigeria, \\ Oșun State College of Technology, Ęsà-Òkè, Nigeria
}

\begin{abstract}
This paper $x$-rays the utilitarian functions and the nature of vehicle inscriptions and stickers in southwestern Nigeria. It traces the history of the use of vehicle writings in Nigeria in general and the southwest in particular chronicling their long history of usage, and noting that it is a common phenomenon nowadays to come across vehicles, most especially commercial ones, heavily bedecked with an array of colourful inscriptions and stickers of different sizes and in different languages and that the posting of the moving emblems on vehicles has become so prevalent and so widespread that there is hardly an automobile on the highways in South-western Nigeria that does not transport them. Our study also reveals that vehicle insignia are meant to serve different purposes some of which include construction of religious messages, moral/philosophical messages, group/individual identity messages, warning and cautionary messages, humours, wits, ribaldry, advertising, politics and public enlightenment messages among several others. Our study further reveals that inscriptions and stickers serve as formidable communicative tools used to transmit diverse messages to the decoders.
\end{abstract}

Keywords: vehicle inscriptions, vehicle stickers, language, nation, heterogeneous society

\section{Introduction}

Nigeria is undoubtedly a multi-lingual, multi-cultural and multi-religious nation. According to Gumperz (1972, p. 230), a multilingual society exists:

where populations of widely different cultural and linguistic backgrounds live in close geographical proximity, subject to the same political authority, attend the same schools, exchange services and cooperate in many other joint activities by means of not one, but a variety of languages.

The heterogeneous nature of Nigeria is a consequence of its historical antecedent of contact which dates back to 1553 or thereabouts when the Portuguese merchants arrived at the West African coasts for commercial and evangelizing activities (see Ajayi, 1965, Adeniran, 1978, Adetugbo, 1979 and Awonusi, 2004). When the British later introduced education into the country, some Nigerians were trained as interpreters and began to use English as a medium of interaction. Thus, the years of interaction between Niger area (later known as Nigeria) and Europe, first in trading activities and later in the propagation of religious activities, brought the English culture and language closer to Nigerians.

At the dawn of independence in 1960, Hausa, Igbo and Yorùbá languages were officially recognized as the three major languages for use. The introduction of the 
trilingual policy was, indeed, a watershed in the nation's educational policy as official recognition was given to the three languages. So, in 1977, through the instrumentality of the National Policy on Education, Hausa, Igbo and Yorùbá became school subjects across the nation's educational levels. The linguistic situation in the country today presents a multiplicity of languages. Research studies put the estimates of indigenous languages between 200 and 500 (see Bamgbose, 1971). The multiplicity of the ethnic languages notwithstanding, only three languages are accorded official status by the Federal Government through the instrumentality of the 1977 National Policy on Education (later revised in 1998 and 1999). They are Hausa, Igbo and Yorùbá. The three indigenous languages acquire the status of official languages in that they possess integrative force. They were the first to be reduced to writing in the mid-19th century with substantial literatures and they have a considerable national and international coverage of users (see Babajide, 2001, pp. 213).

Furthermore, as contact between the European merchants and the natives on Nigeria's coastal areas such as Lagos and the Niger Delta became more noticeable, the need to evolve a common language that would enhance mutual intelligibility between the natives and the colonialists became necessary. As the white men could not communicate effectively with their host natives in English, the adoption of the Nigerian Pidgin as a trade language as well as a channel to meet the communication needs of the people of diverse ethno-linguistic origins emerged. The need to adopt Nigerian Pidgin as a viable linguistic code then was, first, to broaden contact between the white men and the natives and, second, to neutralize the linguistic heterogeneity of the Niger Delta (see Egbokhare, 2001, p. 108). Today, due to its role as a popular linguistic form of communication among the multi-ethnic regions of the country, the Nigerian Pidgin is no longer associated with a low or inferior social status as was the case during the slave trade period. The code has now assumed a wide communicative role as a lingua franca. The code is widely used in the media; it is used for commercial activities as well as a medium in the literary circle.

Similarly, another speech form known as the Arabic language is also in use in Nigeria. It is the sixth after English, Hausa, Igbo, Yorùbá and pidgin that can be discussed under the multi-lingual nature of the country. Therefore, the plurality of the nation's linguistic picture is accentuated by the existence of such exoglossic languages as Arabic, English and Pidgin English alongside the three indigenous languages of Hausa, Igbo and Yorùbá. Arabic language, according to Adegbija (1994, p. 15), is 'the vehicle of Islam' because it is the language of Muslim religion even though it is not all the adherents of the religion that understand the language. In this paper, we show that vehicle inscriptions and stickers express and exemplify the multi-lingual, multicultural and multi-religious nature of Nigeria.

\section{Some Previous Studies}

A few research studies have been published on vehicle writings and their communicative functions (see Jordan, 1978, Ajani, 1999, Chiluwa, 2008, Nwagbara, 2008, van der Geest, 2009, Mgbemena, 2013 and Oduro-Frimpong, 2013). These scholars, however, hold divergent views on such sociocultural factors like age, sex, status, ethnicity and religion that actually influence the use of inscriptions and stickers on vehicles. For instance, while some attribute vehicle inscriptions to the users' behavioural traits, claiming that the writings on vehicles are symbolic of, and analogous to, the idiosyncrasies of the users (see Jordan, 1978 and van der Geest, 2009), others argue that the inscriptions are responses to the users' experiences of life, their fears, anxieties and other challenges of life and the need to seek God for possible solutions (see Chiluwa, 2008 and Nwagbara, 2010). In his study of vehicle writings in five west African countries of Ghana, Burkina Faso, Ivory Coast, Togo and Nigeria, Jordan (1978), for instance, examines what he calls 'role separation behaviours' of commercial drivers (when driving and when not on job) as depicted in the vehicle inscriptions. He argues, in his study, that the writings on the vehicles are true reflections of the behavioural attitudes of the drivers (see also Ajani, 1999). Jordan's (1978) submission 
may not be completely valid, though it may be true that some vehicle users depict their character traits through the use of inscriptions on their vehicles as we can find in some instances.

On the other hand, it may sound reasonable to say that sometimes, some vehicle operators who, possibly, are not the real owners of the vehicles they operate may tend to exhibit a complete antithesis of the behavioural traits of the vehicle owners. For, a vehicle owner may decide to have sùurrù (patience) inscribed on the body of his vehicle as an alias because of his characteristically patient disposition, but may employ a rash and impatient driver operating his vehicle. Hence, a commercial vehicle which has the inscription sùúrù (patience) on its body may, surprisingly, be found to be operated by a driver who is anything but patient. In other words, the fact that a commercial vehicle has the inscription sùurrù (patience) on its body, does not strictly imply that the vehicle operator will maintain a patient disposition; otherwise, frequent carnages on Nigerian roads, which are majorly caused by sheer impatience on the part of most vehicle operators, would have been a rare occurrence. So Jordan's (1978) strict attribution of the drivers' behaviour to the inscriptions on their vehicles as if to say that the vehicle inscriptions bear the true reflections of the drivers' behaviour constitute one of the weaknesses inherent in the study. Our assumption is that the user may have either borrowed it for use or may be a driver operating it for commercial purpose.

Chiluwa's (2008) study is another research endeavour that studies the religious value of vehicle inscriptions. His study primarily discusses vehicle stickers as a medium for communicating religious beliefs. The study takes a critical look at vehicle stickers as they are used to construct individual and group identities, people's religious faith and social vision in the context of religious assumptions and practices in Nigeria. While discussing the discourse context of religious stickers on selected commercial vehicles in Nigeria, Chiluwa (2008) observes that religious vehicle stickers are used to express social vision, individual group identity as well as a means of reaffirming faith by religious adherents. In the study, he argues that individuals using the stickers that construct social vision do experience in real life some hard times, but are made to believe that operating in the tradition of the popular positive confession would change their social condition for the better. In the study, too, he remarks that religious stickers are used as a 'quest for self-identity' as adherent of certain religious groups in Nigeria procure car stickers for the purpose of identification. By sticking the insignia on their vehicles, individual church members are able to identify one another and, consequently, are likely to offer assistance to any of the members in need of help. However, his assertion that 'members who do not use stickers because they do not own cars are insulated from assistance as they are often neglected or mistakenly ill-treated by their fellow brothers and sisters' may not be a completely valid statement in that stickers have become so ubiquitous and widespread nowadays that they are not restricted to vehicles alone. In addition, therefore, whether they are used on vehicles or not does not necessarily insulate the users from possible assistance from their fellow brethren. This implies that any member of a religious faith who does not own a car to use the sticker on can, as well, decide to fix the insignia on their bags, Bible or Quran as the case may be while the same purpose of group/individual identification can still be maintained or achieved. While we may agree with Chiluwa's (2008) argument that stickers communicate group/individual identification of the users, we also want to argue in this study that vehicle inscriptions or stickers provide a rich platform for other domains of discourse than group/individual identity as claimed by Chiluwa (2008). As a matter of fact, there are quite a lot of other domains in which vehicle writings can serve communicative purpose. Some of these domains are shown in our findings.

Writing on vehicle inscriptions as a medium of communication, Nwagbara (2008), like Chiluwa (2008), notes that vehicle insignia arguably represents the single most important factor for ideological change. He argues that the impact of vehicle inscriptions extends 
across the totality of human existence; from cultural transformation to political and ideological change. While we agree with Nwagbara (2008) that vehicle inscriptions construct political and ideological ideas, we want to add too that the utilitarian dimension of vehicle inscriptions and writings has never been in doubt. For instance, they have proved to be an excellent advertising tool as more and more companies have realised the potential of this tool and have begun to use it on the vehicles to promote their businesses. We also show in this present study that vehicle inscriptions play important roles in lot of ways other than for political or ideological reasons as they are also employed to enlighten, rebuke, educate and promote different aspects of the socio-cultural values of the society as well as promotion of favourite club sides and advertisements of products, goods and services. Similarly, spiritual and philosophical beliefs are also constructed through vehicle inscriptions and stickers. In addition, vehicle writings have, in recent times, become a unique way of expressing core values in organizations. The corporate image of an organization is inextricably linked to its mission statement. In other words, the success of an organization is often tied to how well it does in achieving its mission statement, and the role of vehicle inscriptions in this regard is exemplified by a study on the expression of core values through bumper stickers at Goshen College, Northern Indiana (see Evans, Pletcher and Stolzfus, 2012).

\section{The Utilitarian Functions and the Nature of Vehicle Writings}

In this section, we present the utilitarian functions and uses of vehicle inscriptions and stickers in Nigeria. First, we take a general look at the functions of vehicle inscriptions in Nigeria, which is then followed by instances in the use of vehicle stickers and finally those areas in which the use of inscriptions intersects those of stickers. This section will equally take a global look at the utilitarian functions of the inscription and sticker emblems so as to validate our claim that the use of this mobile insignia transcends the Nigerian shores. The history of the use of vehicle inscriptions in the country will serve as the starting point for our discussion. The purpose is meant to confirm that the utilitarian functions of vehicle writings in Southwest in particular and Nigeria in general has had a fairly long history. Inscriptions refer to words written in the front of a book or in any part of other objects like vehicles and buildings. They are artistic writings on paints. We can also say that vehicle inscriptions refer to 'written texts, drawings, images, messages, paintings and photographs, among others which are inscribed on the panel of vehicles'. They are written texts because they constitute a form of discourse the purpose of which is to form a unified whole as well as communicate a certain message (see Halliday and Hassan, 1976, Bloor and Bloor, 2004). For instance, Bloor and Bloor $(2004$, p. 5) define a text as 'any stretch of language, regardless of length, that is spoken or written for the purpose of communication by real people in actual circumstances'.

Similarly, since the inception of automobiles in Nigeria, vehicle users have been using inscriptions in the form of artistic paints on their vehicles. Graphic artists, popularly called sign-writers, who were skilled in motor painting and graphic art, were usually employed in those days by vehicle owners to paint their newly bought vehicles such as Bedford, Austin and Mercedes Benz 911, to mention but a few and inscribe captions of their choices on the bodies of their vehicles, partly for aesthetic purpose and partly for communicative purpose. In the early years of vehicle use in Nigeria, inscriptions on vehicles were more of aesthetic than communicative purpose. This is because the few vehicle owners then would go at any length to ensure that their vehicles looked beautiful, colourful and mesmerizing. Not that alone, having richly adorned the windscreens, bodies and the inside of their vehicles with different inscriptions, they would also install their vehicles with a pair of big horns that looked like a bugle from which a loud supersonic hoot would sound. Funny enough, passers-by that heard the hooting hunk would think it was coming from a locomotive because of the loud and intimidating sound that would come from such automobiles. On the other hand, some pedestrians that heard the hooting honk might, in sheer admiration and excitement, interpret the sound to have meant, Mo șèssè bèrrè ayé jíje $n i$ (meaning 'I have just started enjoying my 
life'). The practice was a means of demonstrating users' or owners' social pedigree in the comity of vehicle owners. This practice is still in vogue till date as many vehicle operators, having adorned their automobiles with different inscriptions in varying colours, will also go an extra mile by installing large horns on their vehicles to make such a loud noise that anyone from a far distance can distinctly hear it. The colourfully written inscription texts on vehicles as well as the supersonic horns that were meticulously hung on driver's side are meant to complement the aesthetic quality of such vehicles. Vehicle owners and the general public have now realised that vehicle insignia offer an excellent potential for communication in social situations apart from the aesthetic functions they had earlier associated the writings with.

Furthermore, as a communicative artefact, inscriptions are of two types: the paint and the metal or gold inscriptions. The former is the type in which oil paint is used to inscribe messages on the body of an automobile. It is a work of art undertaken by sign-writers to capture the realities of human experiences. It is usually in form of graphic and visual artistic patterns. Vehicle inscriptions are eloquent semiotic means of encoding certain ideas and concepts to the readers. For instance, quite apart from the type that is artistically embossed on vehicles which convey a wide range of messages, there are still others that are used to display code numbers on each side of a vehicle such as intra-city cabs and minibuses popularly referred to as kórópe, dáńfó and móòlùè as well as government utility vehicles for safety, identification and demographic purposes. The number code is issued by every government agency saddled with such a responsibility, and the code is thereafter taken to a sign-writer's studio who will emboss the number on such a vehicle for various purposes one of which is to determine the demographic trends of intra-city commercial vehicles and government utility vehicles in each state.

Another category of vehicle inscription is the gold or metal inscription. It is in two forms. The first is used on vehicles to delineate vehicle brands. The labelling of the metal or gold emblem on vehicles usually represents the trade mark of the manufacturers of such automobiles. The labelling is meant to afford prospective buyers of any of the vehicles on display the opportunity to select from the variety of brands available to them. It is no gainsaying that some vehicle users do make a strong preference for a particular brand of vehicles against the others just in the same way as vehicle owners express preference for vehicle numbers belonging to certain states in the Federation. Such metal inscriptions are those that classify vehicles as either Toyota, Datsun, Honda, Primeria, Almera, Peugeot, Audi, Volkswagon, Volvo, Mercedes Benz, Mazda or Jeep (Sport Utility Vehicle SUV), each indicating the manufacturing company from which the automobiles were produced. The second type is a rather novel idea. It is referred to as state logo identification insignia. The type is embossed below the number plate of every automobile to indicate the state from which a vehicle was registered. For example, Land of Honour, Heartbeat of Nigeria, Centre of Excellence, Sunshine State, Confluence State, State of Harmony, Gateway State, Pacesetter State, Land of Virtue and Centre of Unity to mention but a few are the slogans embossed on the number plates of vehicles believed to have been registered in Èkìtì, Edo, Lagos, Oǹdó, Kogí, Kwara, Ògùn, Oyó and Oșun states and Abuja, the Federal Capital Territory respectively.

In some cases, too, metal inscriptions on the number plates of vehicles are utilised to inform the public about the social pedigree of the owners of such automobiles. Essentially, there are three categories of number plates issued to vehicle owners by the Federal Road Safety Corps (FRSC). They are: Standard, Fancy and Out of Series. The Standard is also known as the general type which is the common type issued to any vehicle owner at a regulated cost upon meeting all the requirements stipulated by the Motor Vehicle Administration (MVA)Department of the Federal Road Safety Commission (FRSC). The registration fee depends on the state of the Federation from which issuance is made. For example, it is generally believed that it is much costlier or more expensive to obtain a vehicle registration number from either Lagos State or Abuja (the 
federal capital) than from any other states of the Federation. By this token, it is only those who can afford the high cost of registering their vehicles in either of those two highly urbanised and frequently preferred states that do so. Other vehicle owners who cannot afford the high cost will prefer to register their vehicles in other states whose registration fees are not as high.

The Fancy and Out of Series types are the customised types. They both attract a higher cost from any vehicle owner who wishes to obtain either of the two types because of their specialised nature. The Out of Series type of number plate is obtained when owner of a new vehicle decides to customise his/her vehicle registration number. It is very expensive and often bought or used by few vehicle owners. It is only those who belong to a high social class such as the politicians, business moguls, notable 'Obas', 'Emirs', 'Obis', captains of industries and other categories of influential personalities in the society that usually go for the Fancy or Out of Series type. Instances of Out of Series class of number plates include the number plates of notable personalities in the society who have decided to customise their vehicles for the purpose of exhibiting their affluence and influence in the society. Oftentimes, it is possible for one to come across private vehicles that convey the Out of Series number plates like Olólá-2, Yèyélájé, Otúnba, Yèyé Oge, Adégoróyè, De Guv and Owónikókó, to mention but a few. They are vehicle insignia specifically peculiar to private vehicle owners, and they are used to depict the social status of the users.

Moreover, a rather novel dimension to the Out of Series Class of number plates is the one that depicts the business of the vehicle owner. Some Nigerian business moguls usually specially order for the Out of Series Class. In most cases, they associate the customised number plates with the kind of professions in which they engage. This practice is quite new and recent, and it is done for different purposes ranging from advertisements of products to delineation of social status. For example, Ebony Funeral Ltd is an undertaker company that is widely known in the southwest and beyond. It specializes in arranging funeral activities. The organization offers multipurpose funeral services and burial advisory service which include sales of befitting caskets, organization of pall bearers at burial ceremonies and also hiring of hearse that conveys the coffin. The undertaker company has the two types of Out of Series number plate on its fleet of vehicles for identification. The number plate that has either the name of the company (EBONY) or a gold-plated number like 6FT boldly engraved on the number plate is usually hung on the bumper of the hearse and all other vehicles that belong to the company. The inscription (either EBONY or 6FT) on the bumper of the utility vehicles of the company speaks volumes about the nature of business of the company.

The Fancy type equally is an exclusive type. It is of a high quality and is used by institutionalized bodies such as government agencies, institutions of higher learning, ministries, parastatals and members of diplomatic corps. The instance of few individuals in the society specially requesting for customized number plates from the issuing agency may not be unlikely in a stratified society like Nigeria where class and occupation constitute very important sociolinguistic markers. Since the study of sociolinguistics covers the relationship between social class and language variety, it is valid to assume that one of the ways in which people construct their identities and status in the society is through the use of the exclusive type of metal inscriptions on the number plates of their vehicles. This type reveals the socio-economic status as well as the profession of the owners of the vehicles on which customized number plates are hung. Such customized vehicle inscriptions which are believed to belong to owners of vehicles who occupy high social strata in the society are quite common on the major roads in Nigeria. All of these categories are of interest to this paper.

The history of the use of vehicle inscriptions in Nigeria is shrouded in obscurity. This is because there is no known history of the use of these moving emblems in the country. The scanty literatures on this research study were imprecise about the exact period vehicle inscriptions emerged in the country. For instance, Chiluwa (2008, p. 373) 
traces the inception of the art of inscribing phrases and sentences on vehicles to the early 70s. According to him, the most common inscriptions on vehicles then bore such writings as 'goods only', 'private' or 'goods or owner's risk' (see Chiluwa 2008, pp. 373-374). While we agree that the examples of vehicle inscriptions cited above used to be some of the few inscriptions on the bodies of vehicles then, we, however, argue here that the use of vehicle inscription actually predates this period. In fact, the history can be traced to the beginning of the use of automobiles in the country. Our argument is based on the premises that, first, Nigeria is a former British colony, and the British administrators that ruled Nigeria before independence were believed to have owned automobiles on which a few inscriptions must have been written.

Second, when the colonial administrators left the Nigerian shores and the country attained political independence in 1960, Nigerians too were believed to have had their own vehicles on which they inscribed phrases and sentences that conveyed a variety of messages to the reading public. In other words, shortly after independence, it is assumed that Nigerians among whom were budding politicians, small and large scale business entrepreneurs, civil servants and transporters owned their own cars, buses and lorries. It was indeed a period when professional drivers found it fashionable to inscribe catchy phrases on the bodies of their vehicles for aesthetic purpose as a demonstration of their ownership of automobiles in the comity of vehicle users. Then, such vehicle inscriptions as: Fálànà gbớ tìe (Mind your own business), Igi á rúwé (The tree will sprout leaves), Àti dádé kìniún (Before the crowning of the lion), Kóroò tó dayờ (Before a situation turns joyous), Àbùsí Èdùmàrè (Over-flowing blessings of the Almighty God), 'Why worry', 'Sea Never Dry', Nagode Allah (Thank you God), and 'Man go wack' among other inscriptions were in much use, especially between the 60s and mid 70s.It is however, interesting to note that those vehicle writings were popular and notable for the profound messages they conveyed to the public. Besides, many of those inscriptions depicted the philosophies and the world-views of the owners or operators of the vehicles.
Another reason that can be adduced for the long history of the art of inscribing words and phrases on vehicles is that vehicle owners in those days used to keep their old, rickety and unserviceable vehicles in front of their houses as relics instead of disposing of them. The vehicles were usually parked in front of their owners' houses to serve as reminders of their first ownership of automobiles. Our findings revealed that most of these decrepit and stationary vehicles parked in front of owners' houses or at the mechanic workshops used to carry faint and weather-beaten inscriptions with faint registration numbers which bore semblance of the period between 1953 and 1962 when Nigeria had three regions of South, West and North. Vehicles on which some of those inscriptions were found used to carry such quaint number plates as: WE 7449, WD 3612, LW 1940, WC 1212 and WF 3378 indicating registration numbers from Abẹ́òkúta, Oǹdó, Lagos, Òșogbo and Ifè̀ respectively. Those old and extinct registration numbers were number plates common in the Western part of Nigeria in the 60s. The orthography of many of the writings on vehicles is another factor which suggests that the history of vehicle writings has been quite long; for, spellings on those vehicles were quaint and suggestive of the type of spellings in vogue before the inauguration in 1977 of the Committee on Yoruba Orthography. Examples of such inscriptions include, but are not limited to the following: Aiye loja (The world is a market place) instead of Ayé lojà, Suru logun aiye (Patience is the medicine of life) instead of Sùúrù loògùn ayé and Aro lawa(The crippled will drive it) instead of Àárọ̀ la wà (We are in the morning [of our lives]). Some would jokingly say, 'Èmi ò lè wọkọ̀ táro máa wà' (I cannot board a vehicle that will be driven by a crippled driver!).

In addition, the vehicles on which some of these inscriptions were found used to serve as mini-kiosks and make-shift 'restaurants' where the mechanics in whose workshops the vehicles were abandoned usually kept their working tools, took their meals and even took a nap when there was no patronage. The above facts serve as reasons for claiming that the history of vehicle writings in Nigeria predates 
the 70s. However, when commuter buses known as móòlùè and dánfó in the Southwest and kelukelu in the East later became another popular means of transportation, more inscriptions that constructed more concepts and larger world views emerged. By the 1970s, vehicle inscriptions quickly gained patronage and prominence, and over the years, have served a wide range of purposes. They provided social commentary on current affairs; they elucidated on social and political events; they reflected the users' prevailing circumstances as well as espoused political ideologies. They also reflected the users' personal philosophies and constructed warnings to public safety. They have also become potent media for class placement with varying messages to depict vehicle typology.

By the turn of the $60 \mathrm{~s}$, vehicle inscriptions had gained unprecedented prominence as they used to serve as nicknames or metonymy for the users. A nickname, according to Hornby (2000: 790), 'is an informal, often humorous, name for a person that is connected with their real name, their personality, or appearance, or with something they have done'. Ajíleye and Ajíleye (1997, p. $195)$ cited in Quercoopome (1987, p. 118) also remark that 'a nick-name gives an individual a distinct character and makes a person become united in one body with the society'. Hornby (ibid) defines metonymy 'as the act of referring to something by the name of something else that is closely related to it...' Metonymy too involves replacing the name of something with something that is connected to it without being the whole thing. For example, 'Aso Rock' which is the seat of government in Abuja, Nigeria is synonymous with the Presidency just in the same way as the White House is symbolic of the US Presidential residence and administrative centre in Washington D.C. The point being made here is that inscriptions reveal a lot about the users and the society/culture to which the users belong. In other words, they can tell the public about who the users are. There have been occasions, for instance, when vehicle users/owners were addressed by the inscriptions on the bodies of their automobiles. In some parts of the country in the $60 \mathrm{~s}$, for instance, there were instances when vehicle users /owners used to be known and addressed by the inscriptions on their vehicles. They were hardly addressed by their real names, most especially by those who were not closely related to them. Instead, the catchy inscriptions on their vehicles were generally taken for the owners' personal names. In such cases, the inscriptions on their vehicles eventually became their aliases, nick-names or even surnames. It was very common then to hear the public, especially the regular customers or close associates of those vehicle users/owners, saying: Mótò Sùúrù ni mò ń bá lo sí Ėkó lọ́la (It is Sùúrù's vehicle that I will board to Lagos tomorrow), Mò ń lo sớdọ Bàbá Iréwolé (I am going to Iréwolés father). One of the researchers still remembers with nostalgia that in the early 60s, there used to be a famous transporter in his town then who was popularly called Bàbá Àmòó(which was not the real name) because the inscription on his fleet of commercial vehicles which he was using for transportation bore the inscription: T'Olúwa ni yó se, $A$. Àmòó. It is interesting to remark that only a handful of people in the locality knew him by his real name. Others, especially those who were not too close to him, knew him by the trade name on his fleet of vehicles.

Similarly, the owners of the ageless yet thriving transport companies in the Eastern part of the country are simply referred to as Ekene Dili Chukwu, 'The young shall grow' and 'ABC' up till now even when the names are not their personal names. The names are just the brand or trade names of those transport companies rather than the real names of the owners. This phenomenon is not peculiar to Nigeria alone. In his study of vehicle inscriptions in Ghana, for instance, OduroFrimpong (2013, p. 3) remarks that:

I observed how drivers referred to one another either by the full or an abbreviated form of the inscriptions on their vehicles. As some of them intimated, in most cases, their fellow drivers do not know one another's actual names. All the drivers I interviewed were known by their vehicle inscriptions only and 'owned' such inscriptions because they evolved from their own personal experiences.

The above excerpt underlines the fact that most drivers of the vehicles who use inscriptions that later become their aliases or 
nicknames may not have necessarily been the owners of the vehicles they drive. The fact is that most of those drivers may have had very good working relationships with their masters and some of these bosses do allow the drivers to write their preferred inscriptions on the vehicles.

It is important to know more about the philosophies behind some of these sayings. Some of the messages are words of wisdom; others are of hope, belief, expression of frustration, advice to others, or acknowledgement of God's blessings and supremacy. The drivers do not just write what they like; the words really mean something to them. Sometimes, they emanate from some deep sub-conscious desires. Something may have happened to the driver or car owner in the past that finds an expression in the slogan on the vehicle. Sometimes, through the efforts, seriousness and dedication of drivers, owners have been able to increase the number of buses in their fleet. So, when one sees inscriptions like 'Honest Labour' or 'No food for a lazy man' written on a vehicle, one must think of what lies behind. This, in essence, implies that most of the writings we see are not just there for ornamental purpose, but there is always a philosophy behind such writings. According to Oduro-Frimpong (ibid), vehicle inscriptions are 'based on people's experiences... as these inscriptions are embedded in human interpersonal relationships and on careful reflection, in personal social experience'.

Another interesting thing about vehicle inscriptions is that sometimes, both the drivers and the artists are illiterate and they write grammar or spelling that is funny when read by the public. The funny aspect is that neither the artists nor the drivers of the automobiles that transport such writings are really aware of the errors inherent in the captions. Even when their attention is drawn to the errors, they seem not to care about the negative signal which the deviant grammatical expressions send to the reading public. The illiterate drivers merely drive away gleefully with such grammatically inept inscriptions as 'God day', 'Holly Ghost', God time', 'Nobody know tomorrow', 'Noting pass God', 'God Favour', 'No king has god' and a host of other ungrammatical expressions instead of 'God dey', 'Holy Ghost', 'God's time', 'Nobody knows tomorrow', 'Nothing passes God', 'God's Favour' and 'No King as God' respectively. Interestingly, some of the artists are so gifted and write beautiful fonts that present an eyecatching effect on vehicles. Others are poor calligraphers who scribble art pieces that are mere eye-sores. However, modern civilizations, the penchant for social prestige and advancement in science and technology have given birth to the emergence of stickers as another means of communication among vehicle owners. In other words, the use of stickers on vehicles for communicative purpose is a recent phenomenon. It is an outgrowth of advancement in science and technology. A sticker, according to Wikipedia (https://en. m. wikipedia.org>wiki> Bumper, accessed $18^{\text {th }}$ June, 2017), 'is a type of a piece of paper or plastic, sticky on one side, and usually with a design and a message on the other'. The adhesive material today enjoys unparalleled patronage and popularity in homes, by vehicle owners as well as commercial motorcycle operators popularly called 'ọkkadà' riders.

Today, vehicle stickers seem to have assumed a ubiquitous status: they are found almost everywhere. They are hawked at the motor parks, motor spare parts shops and along the road sides. The use of stickers on vehicles began to gain prominence and attract high patronage at the early part of the $80 \mathrm{~s}$. It received tremendous and unprecedented upsurge in the 80s when the country began to witness a rapid technological advancement in screen-printing technology. The culture of posting sticker on almost every conceivable object is a very remarkable phenomenon these days. Almost every tangible object, however small, has a sticker stuck on it. Objects such as purse, bag, water bottle, plastic materials, household equipment, motor bikes, tricycles, vehicles and a host of other personal effects now attract the patronage of stickers. Vehicle sticker language is often constructed in affective style because the language in which it is constructed affects people's feelings, enters into their imagination, influences their emotions, and often leaves an indelible impression of profound truth. It is important also to note that considerable variation exists 
around the world as to the context and purpose of stickers. This study reveals that there is a preponderance of use of stickers over that of inscriptions because of a higher patronage accorded the stickers. The reasons for the preponderance of use of stickers over inscriptions by vehicles users are many and varied.

As earlier mentioned, modern civilization, and advancement in science and technology have seriously popularized the patronage accorded vehicle stickers. Advancement in electronic and print technology has tremendously given an unprecedented impetus to the popularity stickers enjoy among household materials and vehicles. The reasons for the upsurge of interest in the adhesive material are not far-fetched. One of the reasons, for instance, is that they are very accessible. Their accessibility makes it very convenient for their patrons to purchase them in substantial quantity and post them on the different parts of their automobiles: the front and rear windscreens or both sides of an automobile. The front and rear bumpers of a vehicle, especially a private vehicle, equally carry the adhesive materials. The ornamental and aesthetic emblems can easily be obtained in spare-parts shops and at the road-side. Besides, they are cheap and affordable. As a result of their cheapness, it is common nowadays to come across a large number of automobiles on Nigerian roads heavily bedecked with stickers of varying colours and sizes which, not only add beauty and glamour to the vehicles, but also transmit a myriad of profound messages to the readers.

Similarly, the affordability and accessibility of these moving emblems make them a more common sight than inscriptions because while a vehicle can have only an inscription embossed on it, a variety of sticker emblems can be found on that same vehicle. Moreover, vehicle stickers are not only costeffective, but are also less time-consuming to paste or fix and remove unlike the inscriptions that may take a longer time to inscribe on a vehicle. Users too need not spend fortunes at the sign-writers' studios to inscribe messages on their vehicles. Instead, they can easily go for the cheap stickers which can be removed whenever the users want to replace them with another one. Usually, vehicles are frequently bought and sold, thus necessitating the new owners to remove and replace the old stickers with new ones according to the taste, the profession, the philosophy and religion of the new buyers since vehicle insignia in most cases represent the social, religious and philosophical sentiments of the users. Another reason for the preponderance of vehicle stickers over vehicle inscriptions is that they add to the value of an automobile because of the varying colours in which they are printed. Vehicle stickers add to the aesthetic beauty of automobiles. They possess a more aesthetic value than sign writings and produce a more eye-catching effect that can hardly be matched by sign writings. Therefore, the primary consumers of these vehicle stickers, that is, those who use them on their vehicles, can easily purchase the aesthetic ornaments along the road side at ridiculously low prices, and stick as many as catch their fancy on their vehicles in order to make their vehicles appear mesmerizing and appealing to passengers. Vehicle owners, most especially commercial vehicle owners, relish buying a large quantity of these brilliantly beautiful and captivating sticker emblems and post them on their vehicles partly to adorn their automobiles and partly to flaunt their status in the comity of vehicle owners. In some instances, commercial vehicle users, especially the drivers, use a large quantity of stickers with an array of colourful graphics on their vehicles as a measure of their urbane or civilized nature.

Identification of vehicle registration is a unique feature of stickers on vehicles. This type of insignia is the sticker identifying vehicle registration which is often posted on the inside of most vehicle windscreens as proof of their road worthiness as well as evidence of the fulfilment of the requirements of the Federal Government to allow vehicles to ply Nigerian roads. Such identification tag is usually issued by both the Vehicle Inspection Unit (VIU) and the Federal Road Safety Commission (FRSC). Vehicle users, both private and commercial, are under strict obligation to obtain the sticker emblems as any owner that fails to obtain the emblems usually has his/her vehicle impounded by either the Vehicle Inspection Officers (VIO), the Federal Road Safety Corps (FRSC) or the police. Release of such an impounded vehicle is contingent on payment of 
0loyede

the fine imposed on the vehicle by the authorized vehicle regulatory body. This also makes the number of sticker users to outstrip that of users of inscriptions.

Lastly and far most importantly is the changing nature of language and cultural values. It is a well-known fact that language and culture are inextricably woven and that both are highly dynamic (see Wardhaugh, 1986, Hudson, 1996, Babájídé, 2004 and Akínnàwónù, 2007). In a dynamic sociolinguistic milieu as we find in Nigeria, it is only natural that new vocabularies and novel concepts would invade the contents of vehicle stickers. It is therefore not unexpected that language will continually be responding to the dynamics of the society. Finegan (2004, p. 11) underscores the dynamic nature of language and culture when he remarks that 'human capacity for linguistic inventiveness makes repeated sentences unlikely ....' Finegan's (ibid) remark is a clear indication that the readiness with which words respond to the dictates of the social environment makes language to be generative and re-creative (see also Akínnàwónù, 2007, pp. 6-7 and Omoloso, 2012). For instance, Akínnàwónù (ibid) attests the dynamic nature of language in relation to the changing phases of culture. According to him,

When a new idea crops up, the society develops new linguistic concept adopts it and spreads its understanding to other members of the society. This will eventually lead to increase in their vocabulary. Most often, changes in linguistic vocabularies do occur as a result of exposure to foreign cultures or external influences. The point being emphasized here is that culture is not static just as language is evolutionary. Both language and culture keep evolving as instruments of social engineering.

The above excerpt underscores the reason why the youths and semi-educated commercial drivers of nowadays post all sorts of slangs and neologisms that seem unfamiliar to the older ones on their vehicles. This is as a result of the over-bearing influence of foreign cultures on the youth, especially in the area of music. Although the writings on the stickers may sound deviant and sloppy, they are just products of western civilization as well as the users' exposure to foreign music. While noting that the dynamic nature of language affects all ages, Ajíleye and Ajíleye (1997, p. 13), however, strongly believe that the wind of linguistic dynamism is blowing more noticeably on the youths than the old ones. It is not surprising then that slangs and neologisms as well as funny writings are more commonly found in stickers than inscriptions. Different messages from the simple to the profound, from the secular to the spiritual, attract higher patronage in stickers than inscriptions. Those who use this type of slang and funny expressions on their vehicles, especially the intra-city vehicles, splash those vehicles with different types of the insignia, each conveying its own funny and weird messages. It is not so surprising that intra-city transit buses 'transport' this large quantity of stickers about. The fact is that the stickers are in much greater use than inscriptions because they are costeffective, affordable and can easily be replaced with another one.

In recent times, vehicle stickers have become a formidable platform for advertising goods and services. Such adverts can be posted either on the bumper, on the windscreen or on the body of the vehicle. Examples can be found among buses and articulated vehicles carrying the adverts of any of the mobile communications outfits such as, MTN, GLO, Airtel and Etisalat or those that advertise confectioneries and other products. They are a veritable means of advertising, and they are far more effective and less costly than the radio, television or newspaper advertisement because of the far and distant places covered by the vehicles that transport the advertisements. They equally serve not only as identity markers to the users, but also as an effective medium towards evangelizing. Since our sense of self is usually delineated along the clines of race, ethnicity/tribe, language, nationality, gender, age, marital/social status and religion, it is to be expected, that every religion should have identity markers that help determine its status and role in the society. Adherents of each of the religions in this respect express total allegiance to the sects to which they belong. One of the ways by which 
this allegiance is demonstrated is eloquently and semiotically through the use of stickers on the vehicles.

Adherents of certain religious denominations often use the emblems on their bags or purses; in homes, on their Holy Books (either the Bible or the Quran), on their vehicles or any other object to identify their religious faith and propagate same to the public. It is also a means through which religious bodies articulate their ideas, their religious beliefs and philosophies to the public, thereby making the public see their organizations as being 'patronizable'. Examples of such sticker texts that are posted on the dashboards or bumpers of vehicles include, among several others, Celestial Family, Givers never lack, Back to sender, Anglican Family, Baptist Family, I am proud to be a Catholic, Foursquare, Winner and I am a member of Seventh Day Adventist all of which refer to the Christian faithful. The Muslim faithful too use sticker identifiers on their vehicles or other personal effects. Such sticker writings include: Quareeb, NASFAT, Bismillahi, S.A.W (the usual praise name for Allah). They serve not only as totems or identity markers for the users but also as a popular medium to express wishes and desires for a particular year or season among the Christian faithful. For instance, it is not an uncommon phenomenon among churches in Nigeria to articulate their watchwords for a particular year on specially designed stickers which the members of such Christian organizations buy with zeal and passion and fix same in their homes or on other personal effects like vehicles, bags, purses and other objects. The messages contained in the emblems may include the following: 2012: My Year of Elevation, 2012: My Year of Glory, 2013: My Year of New Song, 2013: My Year of Divine Favour, 2013: My Year of Laughter, Unshakeable 2014, EXPLOITS 2014, 2015: My Year of Faithful Worship and 2016: My Year of Divine Presence and Rest. Such occasional vehicle emblems are many and varied because of the proliferation of religious places in Nigeria. They are often bought by the faithful in appreciable quantity and presented as gifts to friends and relations who are not necessarily members of their denomination. The divine messages inherent in the stickers are held sacrosanct by the adherents of the Christian faiths because of their implicit belief that the promises contained in the messages have been divinely sanctioned and, consequently, will surely come to pass in their lives.

Other instances of the use of stickers can be found in the domain of social engagements, that is, those that construct social activities such as wedding and funeral ceremonies. Vehicles, especially the private ones, which are used on social engagements, usually carry stickers which bear inscriptions like About to Wed, Just Married, Happy Married Life, X weds Y, Good Night, mama, and Celebration of a fulfilled life. This type of stickers can be referred to as occasional stickers because they are relevant only for the occasion for which they are posted. They are later removed from the vehicles on which they are hung immediately the occasion that calls for their use is over. It is to be noted also that the stickers serve both aesthetic and communicative purposes in this context. They not only adorn the number plates on which they are hung, they also communicate the event that warrants their use to the public. Moreover, stickers too serve as objects that give expression to philosophical concepts. For instance, the sticker or inscription text that reads Bí èmí bá wà (If there is life) is a profound expression of a philosophical concept. Other examples of inscriptions that construct philosophical concepts include, Rírò ni tènìyàn (Man proposes), Ėdá ò lárò pin, igi á rúwé (Man should not be under-valued, the tree will sprout leaves), Wẹreé nișé Olúwa (The work of God is with ease), Ojú ení máa là (Whoever will be successful in life), 'Remember your six feet', Kórọ tó dayọ (Before a situation becomes joyous), İbàjé èniyàn (The derision of a man), Ara lamò (Knowing oneself), Oore lópé (Doing good is profitable) and several other philosophical inscriptions and stickers that express, in a variety of ways, profound truth about life situations.

Furthermore, veteran musicians are celebrated on beautifully coloured stickers posted on vehicles by the vehicle users, especially commercial vehicle drivers, partly to express their love and admiration for the musical icons and partly as a consequence of their exposure to the western cultures of which 
music is part. Consequently, fans of notable veteran musicians like King Sunny Adé (K.S.A), Ebenezer Obey, Alhaji Síkírù Àyìndé Barrister, Kollington Àyìnlá, Saheed Òsùpá, Whizkid, Davido, Tu pac and Alhaji Wàsíu Àlàbí Pasuma, to mention but a few, abound among commercial drivers in the Southwest of Nigeria. They are so fond of these musical icons, and they make no pretence of their admiration for them. One of the ways by which they demonstrate this love and admiration is through the use of sticker emblems bearing the portraits of those musical icons. They purchase a variety of stickers that have the full or half portraits of these musical maestros sometimes with their aliases below the pictures and emboss them usually on the front and rear windscreens of their vehicles. For example, a vehicle on which the portrait of Alhaji Síkírù Àyìndé Barrister (the late fuji maestro) is posted will most likely have the alias Alhaji àgbà (Big Alhaji) just below the picture. Equally, Kébé ń Kwara (The agile man from Kwara), Agbo Jésù (Jesus' fold) and Ògá ńlá (Fúji) (Big boss [of Fújì]) are aliases with which Alhaji Kollington Àyìnlá, Lady Evangelist Tópé Àlàbí and Saheed Òsùpá respectively are identified among their numerous fans and admirers. The aliases signal, among other things, the ethnic group as well as the religion to which the musicians belong. Kébé ń Kwara, for instance, indicates that the bearer of the alias is from Kwara state while Agbo Jésù (Jesus' fold) signals that the bearer to which the alias is attached is a Christian. Alhaji àgbà(big Muslim cleric) equally portrays the owner of the alias not only as a Muslim but as a devoted and highly venerated Muslim because of the qualifier àgbà. The users of the emblems are so proud and enthusiastic about the presence of the images of these musicians as if their entire existence depends on the presence of the musicians' portraits on their automobiles.

The high patronage vehicle stickers enjoy, however, does not imply that the use of vehicle inscriptions has gone into oblivion. The vehicle inscriptions are equally in use although in much less frequency. We still come across instances of the use of vehicle inscriptions that construct deep and profound social, religious, political and philosophical ideas. For instance, some segments of the society like the educational institutions and companies still use inscriptions alongside stickers to project the corporate image of their institutions or companies to the public. Inscriptions too are common among móòlùè (18-seater buses that operate in some cosmopolitan cities) and some other commercial vehicles. But the point we are trying to make here is that although inscriptions are still used on some commercial vehicles, nonetheless, vehicle stickers are in much greater use because the latter are cheaper, more accessible, and are much easier to remove and replace than the former. It is interesting to remark at this juncture that both vehicle inscription and sticker texts share similar characteristics in some respect. One remarkable area in which they both intersect is in the area of politics, especially during election period. It is during this period that inscriptions and stickers become useful communicative tools in the hands of politicians. Political inscriptions and stickers on vehicles construct social events and trends. They are considered as a very effective means of getting voters' support in the same manner as the print or electronic media do, even at a much less cost.

In fact, one of the most visually striking ways in which political parties sell themselves during an election is through the use of inscriptions and stickers. Many of these emblems are placed on the front and rear windscreens of vehicles used for political campaigns. In some cases too, the entire bodies of vehicles are branded with the portraits of political figures indicating the political parties to which they belong and the posts or offices they are seeking. The branded vehicles move from one place to another, 'selling' the candidature of the politicians to the generality of the public. The inscriptions and stickers too come in various forms, one of which is in form of slogans. Slogans are devised to persuade and convince; so not surprisingly, political parties use them as part of their persuasive strategies. The varieties of slogans deployed by political parties are in form of inscriptions and stickers. For instance, during the Second Republic in Nigeria's political history, political figures were celebrated in recognition of their contributions to the birth, growth and 
development of the country. Such political icons as Dr Nnamdi Azikwe and Chief Ọbáfémi Awólówọ̀, though dead, still live in the hearts of their admirers because many of their admirers still keep these stickers and inscriptions that bear their portraits as relics. During the period Chief Awólówọ̀ and Dr Azikwe held sway on the nation's political firmament, stickers and inscriptions of their political parties were embossed beautifully on a variety of objects to espouse the political ideals of those frontline politicians. Those national heroes and statesmen were celebrated even after their demise with a lavish display of their portraits on vehicles and other objects. In the present dispensation, too, stickers and inscriptions have become an eloquent means of political engineering by politicians. In the Southwest, for example, two political parties are prominent. They are: the ruling All Progressives Congress (APC) and the opposition party, People's Democratic Party (PDP). Each of the two political parties has its own gubernatorial flag bearer. Each of the flag bearers, too, has his own slogans with which he is identified by the party faithful. While Mr. Akeredolu the Ondo state present governor is popularly known by his admirers as 'Arákùnrin', Alhaji Gbóyèga Oyètólá of Oșun state is fondly called 'İlérí Olúwa'. These slogans briefly but memorably suggest something about the political figures on the inscriptions or stickers that bear their slogans. The slogans of the inscriptions or stickers carry striking characteristics which are constructed purposely to endear them to their readers as well as keep the support of their numerous party faithful.

Another remarkable area of convergence between vehicle inscriptions and stickers is in the crisp construction of messages on the bodies of vehicles. In this manner, a part of an expression, especially a figurative expression like a proverb, is used leaving out the other part for readers to complete. What this implies is that, a segment or a Noun phrase(NP) of a sentence is written only for the readers to complete the other syntactic segment or Verb phrase (VP). Such inscription and sticker texts sometimes constitute what can be termed as jigsaw puzzle aimed at tasking the cognitive domain of the readers. It is only the discerning ones, especially those who are deeply rooted in cultural values and versed in local and figurative sayings that can successfully complete the other segment of the expression. Examples of such crisp and compact inscription and sticker expressions abound on vehicles, especially commercial vehicles. Often times, such vehicles transport wise sayings across the length and breadth of the region for readers to drink, as it were, from the fountain of wisdom which the vehicles disseminate. Such didactic and philosophical sticker and inscription expressions include, 'Human Confidence', 'The fear of God', Àwòdì òkè (The heavenly eagle), Áárò la wà (We are in the dawn of our lives), Fálànà gbó tìe (Mind your own business), Ayé lojà (The world is a market place), Àti dádé kìniún (Before the crowning of the lion), Rírò ni tènìyàn (Man proposes), Tẹní bégi lójù (The hewer of a tree only has something to regret over), Eni a fé la mò̀ (We know only those who love us),The downfall of a man and Ankuri (Patience) to mention but a few. The figurative expressions above, apart from the fact that they are wise sayings and thought-provoking, constitute the syntactic segments of some sentences.

In addition, the full realization of the constituent parts will read thus: 'Human confidence is vanity', 'The fear of God is the beginning of wisdom', Àwòdì òkè kòmò pé ará ilè ń wò òun (The eagle that perches heavenwards does not realise that those beneath are watching it), Àáró la wà, oba jẹ kálé yẹ wá (We are in the dawn of our lives, may it please God to let us end well), Fálànà gbó tìe, tara ęni làá gbớ (Falana, mind your own business as we mind ours), Ayé lojà, òrun nilé (The world is a market place while heaven is [our] home), $\grave{A} t i$ dádé kìniún, kò sèyìn Elédùmarè (The crowning of the lion is not without God's knowledge), Rírò ni tènìyàn, șișé ni ti Olórrun (Man proposes, God disposes), Tẹní bégi lójù, igi á rúwé (The tree feller only dissipates his energy, the tree will [soon] sprout leaves), Enni a fé la mò̀, a kò mẹni tó fẹni (We only know whom we love; we do not know who loves one), 'The downfall of a man is not the end of his life and Ankuri, magani duniyan (Patience is the medicine of the world; that is, patience is needed to survive in the world) respectively. All of these vehicle inscription and sticker insignia constitute a rich source of food-for-thought to the readers. They also act as "philosophical capsules" that capture the users' experiences (see Oduro- 
Frimpong 2013:1). Yankah (2011:15) argues that the vehicle inscriptions and stickers constitute "philosophical summaries" for the drivers. Taluah (2012:3) also says that such crisp and compact expressions as we find above are 'sententious aphorisms, proverbs, puzzles and wise sayings with social and cultural dimensions....'. Moreover, they serve as a remarkable medium aimed at enriching the readers' knowledge about their immediate environments as well as expanding their linguistic and intellectual horizons since proverbs and wise sayings are a part of individuals' cultural heritage.

They are also a very good means of brand recognition. The exposure that a business name and logo will get on vehicle inscriptions and stickers is immense. They 'transport' the names and corporate images of any organizations that use the emblems as far as the vehicles on which they are posted can travel to. Writings, signs and other semiotic icons on vehicles are now a visible phenomenon on many commercial vehicles in Southwest in particular and Nigeria in general. At least, one out of three vehicles that trail along the roads and highways of the cities and various regions in the country carry bold writings and stickers which convey diverse forms of meaning in the texts of their messages. As a matter of fact, the patronage which vehicle inscriptions and stickers are accorded in recent times has been quite unprecedented. A few reasons can be adduced to the spate of patronage which vehicle inscriptions and stickers have been receiving among automobile users. First, there has been an unprecedented surge in vehicular activities between the latter part of the 80 s till date as a result of the various economic policies of the successive governments in the country towards making almost average income earner own a vehicle. As public servants in the country experience the presence of their various employers through enhanced salaries and emoluments, there is a tendency for them to improve their social status. A visible index of an enhanced social status in this respect is undoubtedly a possession of automobiles. As the number of private vehicles increases on the roads, so is the tendency for other sectors to receive an enhanced status too through acquisition of vehicles. It therefore becomes obvious that more vehicles on the road will likely lead to a greater use of vehicle emblems which express divergent messages.

Another factor responsible for the upsurge in vehicular activities is not unconnected with the various mass-oriented programmes of the federal, state and local governments across the country one of which is the mass transit programmes of these three tiers of government. In a bid to impact positively on the lives of the citizenry and make them enjoy the dividends of democracy, successive Nigerian governments have, at one time or the other, introduced mass transit programmes across the three tiers of government. The various programmes are geared towards ameliorating transportation challenges being faced by the masses. In this respect, each local and state governments and the federal government too have their own mass transit programmes with their corresponding logos and inscriptions boldly displayed on the bodies of the vehicles in their fleet. For the purpose of institutional identification, the utility vehicles that serve the purpose of inter/intra city mass transits of those various governments usually carry not only the logos but also the names of the institutional owners of the mass transit buses. The mass transit vehicles are cross-country commercial vehicles, that is to say they travel across all the parts of the country. Some of the intra-and inter-state mass transit vehicles which carry such inscriptions and stickers include, 'Kwara Line', 'Degema Local Government Mass Transit', 'Edo Line', 'In God We Trust', 'Àjùmọ̀se Line', 'Omolúàbí Scholar Bus' (mass transit commercial vehicles owned by the governments of Èkìtì, Oyó and Oșun states respectively), 'Kogi Mass Transit', 'Okene Line', 'Federal Government Assisted Mass Transit', 'Imo Transport Company' (ITC) and a host of others. The mass transit vehicles greatly enhance the patronage which the inscriptions and stickers have continued to receive in recent times.

Moreover, the upsurge in religious activities in the last few years in the country has continued to promote the high prevalence of inscription and sticker expressions. In 
Nigeria, Christianity and Islam are the two prominent religions that attract large followership. Various soul-lifting religious activities such as revival and crusade programmes utilize the medium of the inscriptions and stickers in addition to posters, leaflets, handbills or bill-boards to disseminate information about such programmes. But, in spite of the uses of both inscription and sticker texts as a means of communication, the general trend in the use of those emblems indicates that vehicle stickers and inscriptions are in much greater use than either hand-bills or posters. Although the scope of this study is limited to the Southwest Nigeria, it is not uncommon to come across automobiles that carry stickers, inscriptions and state slogans of other states than the states in the Southwest. For instance, a visit to any part of the country will reveal the unassailable fact that vehicles which carry the stickers, inscriptions and number plate slogans of other ethno-linguistic groups abound in great numbers in those towns and other less cities.

\section{Conclusion}

We have catalogued the history, characteristics and uses of vehicle stickers and inscriptions in Southwest Nigeria. We argue that vehicle stickers and inscriptions constitute a popular medium of discourse as they construct a vital aspect of the culture of communication among vehicle operators in the Southwest of Nigeria. We argue also that vehicle inscriptions and stickers are a popular medium of discourse because, for quite a long time now, writings on vehicles have become a form of communication which has acquired clear-cut artistic and linguistic dimensions. As a veritable medium of meaning generation, vehicle insignia have become ready tools in the hands of vehicle users to communicate a variety of messages to the public. We submit also that as more and more vehicles of different shapes and brands traverse the length and breadth of Nigerian roads daily so can inscriptions on religion, politics, entertainment, enlightenment, moral values and a host of others be found on the bodies of those automobiles in South-west Nigeria.

\section{Acknowledgement}

We are grateful to the Tertiary Education Trust Fund (TETFund) for providing financial assistance to carry out this research work.

\section{References}

Adegbija, E. (1994) "Language Attitudes in Sub-Saharan Africa: A Sociolinguistic Overview." Clevedon: Multilingual Matters.

Adéníran, A. (1978) "Personalities and Policies in the Establishment of English of Northern Nigeria during the British Colonial Administration, 1990-1943". In Journal of the Historical Society of Nigeria. Vol. 9, pp. 105-126.

Adétùgbò̀, A. (1979) "The Development of English in Nigeria up to 1914: A Sociohistorical Perspective". In Journal of the Historical Society of Nigeria. 9 (2), pp. 89-105.

Àjàní, D.T. (1999) "Transporting the Text: Car Stickers as Media of Discourse in Òyó State, Nigeria". An Unpublished M.A. Thesis, Department of English, University of İbàdàn.

Àjàyí, J.F.A. (1965)Christian Missions in Nigeria: 1841-1891. Longman, London.

Ajíléye, M.K. and Ajíléye, S. S. (1997) "Pragma-Sociolinguistic features of Yorùbá Nick-names". In Adébáyo Lawal, (ed.), Stylistics in Theory and Practice. Ilorin: Paragon Books, pp. 195-204.

Akínnáwónù, B.M. (2007) "Logic, Language and Reality". In Bámisayé, T.O (ed.). An Integrated Study in Language and Society 1. Lagos: Majab Publishers, pp. 1-16. 
Awónúsì, V.O. (2004a) “Cycles of Linguistic History: The Development of English in Nigeria". In A.B.K. Dadzie, and S. Awónùsì, (eds.), Nigerian English: Influences and Characteristics. Lagos: Concept Publications Ltd., pp. 46-65.

Babájídé, A.O. (2001) "Language Attitude Patterns of Nigerians". In H. Igboanusi (ed.) Language Conflict in West Africa. İbàdàn: Enicrownfit Publishers, pp. 113.

Babájídé, A.O. (2004) "Decoding Cultural Semantic Undertones in Dialogues". In İbàdàn Journal of English Studies. Ìbàdàn: Gold Press. Vol. 1, pp. 100-116.

Baker, W. (2011) "Soapbox for the Automobile Bumper Sticker History, Identification and Preservation". AltaMira Press. 7 (3), pp. 251-270.

Bámgbósé, A. (1971), “The English Language in Nigeria". In J. Spencer, (ed.). The English Language in West Africa. London: Longman, pp. 35-48.

Bloor, T. \& M. Bloor (2004), The Functional Analysis of English (2nd ed) London: Edward Arnold.

Chiluwa, I. (2008) "Religious Vehicle Stickers in Nigeria: A Discourse of Identity, Faith and Social Vision". Discourse and Communication. 2 (4), pp. 371-378.

Date-Bah, E. (1980) "The Inscriptions on the Vehicles of Ghanaian Commercial Drivers: A Sociological Analysis". In The Journal of Modern African Studies, 18(3), Sept. 1980, pp. 525-531.

Egbokhare, F. (2001) "The Nigerian Linguistic Ecology and the Changing Profiles of Nigerian Pidgin". In $\mathrm{H}$. Igboanusi, (ed.), Language Attitude and Language Conflict In West Africa. Ìbàdàn: Enicrownfit Publishers, pp. 105-124.
Evans, K., Pletcher, A. and Stoltzfus, D. (2012) "Investigating Expression of Core Values Via Bumper Stickers at Goshen College". Available online at: http://www.google.com/se... Accessed November 21, 2015, pp. 1-13.

Federal Government of Nigeria (1981),National Policy on Education(Revised). Lagos: Federal Ministry of Information.

Finegan, E. (2004) (5 $5^{\text {th }}$ edn)Language:Its Structure and Use.U.K.: Thomson Wadson.

Gumperz, J.J (1972) "Sociolinguistics and Communication in Small Groups". In Pride J.B. and Holmes, J. Sociolinguistics: Selected Readings. Harmondsworth, England: Penguin Books, pp. 7-23.

Halliday, M.A.K. and R. Hassan (1976) Cohesion in English. London: Longman.

Halliday, M.A.K. and Hassan, R. (1985)Language, Context and Text: Aspects of Language in a Sociosemiotic Perspective. USA: Donkin University Press.

Holmes, J. (2008)An Introduction to Sociolinguistics.U.K: Pearson Education Ltd.

Hornby, A.S. (2000)Oxford Advanced Learner's Dictionary (6 ${ }^{\text {th }}$ ed.). London: Oxford University Press.

Hudson, R.A. (1996) Sociolinguistics. $2^{\text {nd }}$ edition. Cambridge: Cambridge University Press.

Jordan, W. (1978) "Role Segregation for Fun and Profit: The Daily Behaviour of the West African Lorry Driver". Africa. 48 (1), pp. 30-46.

Mgbemena, J. (2013), "Language, Communication on Wheels and National Development: The Inscriptions on Tricycle (Keke) Example". International Journal of English and Literature. 
http://www.academicjournals.org/IJE $\mathrm{L}$ accessed on November 21, 2015. Vol. 4(10),pp. 529-537.

Nwagbara, A.U. (2008), "Travelling Thoughts, Trailing Texts: Vehicle Writings as Discourse". In Bagwasi M.M, Alimi M.M and P.J. Ebewo (eds.) English Language and Literature: Cross Cultural Currents. New castle upon Tyne: Cambridge Scholars publishing, pp. 85-97.

Oduro-Frimpong, J. (2013), “"Cry Your own Cry": On Popular Visual Media of Life Experiences in Ghanaian Mottonyms". Paper to the European Association of Social Anthropologists (EASA). E-seminar series. Anthropology Network's 43 ${ }^{\text {rd }}$ eseminar, March 26-April 9, 2013. Available online at: http://mediaanthropology.net/index. php/e-seminars accessed on November 21, 2015, pp. 1-23.

Omoloso, R.K. (2012), “A MorphoSociolinguistic Study of Coinages in Yorùbá". In Kuupole, D.D, Bariki, I. and Robert, Y. (eds.) Cross-Currents in Language, Literature and Translation: $A$ Festschrift for Professor J.P.A. Ukoyen. Cotonou: CUREF/: ESSAF \& ESAF, pp. 224.

Osaji, B. (1999),Language Survey of Nigeria. Quebec: International Centre for Research on Bilingualism.

Quercoopome, T.N.O. (1987), "Rites of Passages". In West African Traditional Religion. İbàdàn: A.U.P Pilgrims Books Ltd.

Sjaak van der Geest (2009), “'Anyway!' Lorry Inscriptions in Ghana". In J.B. Gewald, S. Luning and K. van Walraven (eds.), The Speed of Change: Motor Vehicles and People in Africa 1890-2000. Brill Publishers, pp. 1-34.

Taluah, A.R. (2012), "Communicating in the 21st Century: A Linguistic Analysis of Inscriptions on Vehicles". $5^{\text {th }}$ Linguistics of Ghana Annual Conference, Winneba, Ghana. July 29-August 1, 2012.
The Federal Republic of Nigeria, 1977 (revised in 1998). National Policy on Education (3rd edition). Lagos: NERD Press.

Trudgill, P. (1974),Sociolinguistics: An Introduction. Harmondsworth, Middlesex: Penguin Books Ltd.

Wardhaugh, R. (1986),An Introduction to Sociolinguistics. U.K: Blackwell Publishing.

Yankah, K. (2011), "Dzi wo fie asem". In Rhetoric and Politics of expediency in Ghana. Ghana: Ghana Academy of Arts and Sciences Annual Lecture, pp. 4-16. 